\title{
Hubungan Antara Masa Pubertas Dengan Perilaku Diet Pada Remaja Putri Di SMAN 2 Woha
}

\author{
Wahidah \\ STIKES YAHYA BIMA \\ Wahidahstikesyahyabima@yahoo.com, \\ NIDN. 0824118502
}

\begin{abstract}
Abstrak: Remaja adalah bila seseorang telah mencapai umur 10-18 tahun anak perempuan dan 12-20 tahun untuk anak laki-laki dimana pada masa ini terjadi perubahan fisik yang sangat cepat, pertumbuhan yang terjadi pada masa remaja akan mempengaruhi status kesehatan dan gizi tersebut, pada anak perempuan pertumbuhannya lebih cepat daripada anak laki-laki (Sulistyoningsih, 2012). Penelitian ini termasuk jenis penelitian analtik observasional dengan pendekatan cross sectional. Penelitian dekskriptif bertujuan mendeskripsikan masing-masing variabel dan penelitian analtik menyangkut pengujian hepotesis . Populasi dalam penelitian ini populasi yang diteliti adalah semua remaja putri SMAN 2 WOHA sebanyak 85 orang. Dari hasil Penelitian dan Pembahasan yang dilakukan di SMAN 2 WOHA Tahun 2017 dapat disimpulkan bahwa : 1. Hubungan antara masa pubertas dengan perilaku diet pada remaja putri di SMAN 2 WOHA Tahun2017 yang terbanyak yang didapatkan adalah 64 siswi $(92,8 \%)$ pada masa pubertas yang mengkonsumsi, dan terdapat 9 siswi $(56,2 \%)$ pada masa pubertas yang tidak melakukan perilaku diet. 2. Ada hubungan yang bermakna antara Masa Pubertas Dengan Perilaku Diet Pada Remaja Putri Di SMAN 2 WOHA Tahun 2017 dengan Uji statistik Q_value $=(0,000)$. Saran dalam penelitian ini diharapkan pada pemerintah untuk selalu memberikan informasi dan menyediakan informasi untuk remaja dan masyarakat.
\end{abstract}

Kata kunci : Masa Puberitas, Perilaku Diet.

\section{Pendahuluan}

Masa remaja adalah masa transisi antara anak dan dewasa yang terjadi pacu tumbuh (growth spurt), timbul ciri-ciri seks sekunder, tercapai sertilitas dan terjadi perubahan-perubahan psikologik serta kognitif (Soetjiningsih, 2007). Remaja adalah bila seseorang telah mencapai umur 10-18 tahun anak perempuan dan 1220 tahun untuk anak laki-laki dimana pada masa ini terjadi perubahan fisik yang 
sangat cepat, pertumbuhan yang terjadi pada masa remaja akan mempengaruhi status kesehatan dan gizi tersebut, pada anak perempuan pertumbuhannya lebih cepat daripada anak laki-laki (Sulistyoningsih, 2012).

Menurut World Heald Organization sekitar seperlima dari penduduk dunia dari remaja berumur 10-19 tahun. Data demografi di Amerika Serikat menunjukkan jumlah remaja berumur 10-19 tahun sekitar 15\% popilasi. Di indonesia menurut Biro Pusat Statistik kelompok umur 10-19 tahun adalah 22\%, yang terdiri dari remaja. Sedangkan menurut data di kependuduka Dinas Kesehatan Kota dan Kabupaten Bima, kelompok remaja umur 10-19 tahun sejumlah 133.264jiwa ada di kabupaten Bima dan 3.609 jiwa ada di kota Bima. Dari hasil study pendahuluan yang dilakukan di dapatkan status gizi remaja dengan kategori kurus adalah 20,4 \%,kategori normal 64,3\%,kategori berat badan lebih 8,6\%,sedangkan yang obesitas adalah sebanyak 6,8\%, dari hasil penelitian di atas terlihat bahwa prevalensi tertinggi adalah kegemukan untuk pendudukan khususnya remaja putri diantaranya kurang mengetahui perilaku menghadapi masa pubertas yang baik mereka cemas dan gelisah.

Status gizi adalah keadaan tubuh akibat mengkonsumsi dan penggunaan zat-zat gizi. Status gizi baik di usia remaja sangat diperluka tarutama remaja putri karena ini berhubungan dengan peran mereka sebagai calon ibu. Remaja putri yang terpelihara kadar gizinya akan terpelihara kesehatan reproduksinya agar nanti di masa mendatang dimana mereka akan menjadi wanita dewasa yang akan melahirkan generasi berikutnya dan pertambahan berat badannya adekuat (Proverawati dan Wati, 2011). Kondisi seseorang ketika dewasa ditentukan oleh keadaan pada saat remaja.

Remaja merupakan golongan individu yang sedang mencari identitas diri, suka meniru dan mengidolakan seseorang yang berpenampilan menarik, sehingga dalam hal memilih makanan tidak lagi didasarkan pada kandungan gizi, tetapi sekedar bersosialisasi untuk kesenangan dan supaya tidak kehilangan identitas diri. Hal ini akan mempengaruhi kedaan gizi para remaja (Khomsan, 2003).

Faktor perilaku diet, pengetahuan, kepercayaan diri, dan perhatian terhadap citra tubuh merupakan faktor penyebab terjadinya penyimpangan perilaku pada 
masa pubertas. Media, baik media cetak maupun media elektronik dikatakan juga sebagai salah satu faktor yang dapat menyebabkan timbulnya penyimpangan perilaku diet pada remaja. Namun, media cetak lebih memberikan dampak nyata terhadap terjadinya kasus penyimpangan perilaku diet (Gonza'lez, 2003). Banyak remaja khususnya remaja putri menginginkan bentuk tubuh yang sempurna sehingga remaja putri sering tidak percaya diri dengan bentuk tubuh karena dianggap kurang atau tidak ideal baik oleh orang lain maupun oleh dirinya sendiri. Hal itu yang membuat remaja berlomba-lomba mencari upaya bagaimana melakukan diet dengan cepat dan mudah tanpa mengetahui dampak apa yang akan ditimbulkan nantinya (Barasi, 2007).

Salah satu aspek psikologik dari perubahan fisik pada massa pubertas adalah remaja menjadi lebih memperhatikan body image. Remaja putri lebih kurang puas dengan kedaan tubuhnya yang dan memiliki body image yang negatif, dibandingkan remaja putra (Santrock, 2005).

Meningkatnya aktifitas, kehidupan sosial dan kesibukan remaja akan berpengaruh terhadap kebiasaan makan. Pola konsumsi makanan sering tidak teratur, sering jajan, sering tidak makan pagi, dan sama sekali tidak makan siang (Adriani dan Wijartmaji, 2012). Merasa takut akan kegemukan dapat mendorong seseorang melakukan perilaku diet yang salah. Perilaku diet yang salah pada umumnya dapat mengakibatkan terjadinya masalah gangguan makan seperti anoreksia dan bulimia (Khomsan, 2003).

Berdasrakan studi pendahuluan yang dilakukan oleh peneliti di SMAN 2 WOHA Kelas II pada tanggal 08 juni 2017 dapat disimpulkan bahwa perhatian dan pertahanan bentuk tubuh yang ideal sangat kuat terjadi pada masa remaja, baik pada remaja awal maupun pada remaja akhir. Para remaja melakukan berbagai usaha agar mendapatkan bentuk tubuh yang ideal sehingga terlihat menarik. Salah satu usaha tersebut adalah dengan melakukan diet. Dari hasil data awal didapatkan 85 orang siswi yang mengalami masa pubertas.

\section{Metode Penelitian}

Penelitian ini termasuk jenis penelitian analtik observasional dengan pendekatan cross sectional. Penelitian dekskriptif bertujuan mendeskripsikan 
masing-masing variabel dan penelitian analtik menyangkut pengujian hepotesis . Populasi dalam penelitian ini populasi yang diteliti adalah semua remaja putri SMAN 2 WOHA sebanyak 85 orang.

\section{Hasil Penelitian}

\subsubsection{Analisa Bivariat dan Pembahasan}

A. Hubungan Antara Masa Pubertas Dengan Perilaku Diet Pada Remaja Putri Di SMAN 2 WOHA Tahun 2016.

\begin{tabular}{|c|c|c|c|c|c|c|c|}
\hline \multirow{3}{*}{ Masa Pubertas } & \multicolumn{4}{|c|}{ Perilaku Diet } & \multirow{2}{*}{\multicolumn{2}{|c|}{ Jumlah }} & \multirow{2}{*}{$\begin{array}{c}\rho \\
\text { Value }\end{array}$} \\
\hline & \multicolumn{2}{|c|}{ Melakukan } & \multicolumn{2}{|c|}{$\begin{array}{c}\text { Tidak } \\
\text { melakukan }\end{array}$} & & & \\
\hline & F & $\%$ & $\mathrm{f}$ & $\%$ & $\mathrm{~N}$ & $\%$ & \\
\hline Mengkonsumsi & 64 & 92,8 & 5 & 7,2 & 69 & 100 & \\
\hline $\begin{array}{c}\text { Tidak } \\
\text { mengkonsumsi }\end{array}$ & 7 & 43,8 & 9 & 56,2 & 16 & 100 & 0.00 \\
\hline Total & 71 & 83,5 & 14 & 16,5 & 85 & 100 & \\
\hline
\end{tabular}

Berdasarkan tabeldiatas dapatdiketahui dari 85 remaja siswi, terdapat 64 siswi $(92,8 \%)$ pada masa pubertas yang mengkonsumsi, dan terdapat 9 siswi $(56,2)$ pada masa pubertas yang tidak melakukan perilaku diet.

Berdasarkan hasil uji statistic Chi square didapatkan @ Value = $(0,000)<\alpha=0,05$. Hal ini menunjukan bahwa ada hubungan yang signifikan antara masa pubertas dengan perilaku diet pada remaja, sehingga hipotesis awal menyatakan ada hubungan yang bermakna antara masa pubertas tarhadap perilaku diet.

\section{Pembahasan}

\subsubsection{Masa Pubertas}

Hasil penelitian ini menunjukkan bahwa yang terbanyak yaitu siswi pada masa pubertas yang mengkonsumsi adalah sebanyak 69 siswi $(81,2)$. Tingginya 
angka kejadian ini seiring berdasarkan proses perkembangan remaja yang menampakan pengungkapan kebebasan diri dalam segala hal, memiliki citra atau (gambaran, keadaan, peranan) terhadap dirinya, dapat mewujudkan perasaan cinta, memiliki kemampuan berpikir khayal atau abstrak.Pada masa ini individu menunjukan keinginan dalam mengoleksi penampilan yang lebih selektif.

Menurut Widyastuti (2011) Masa remaja, yakni antara usia 10-19 tahun,adalah suatu periode masa pematangan organ reproduksi manusia, dan sering disebut Masa Pubertas. Pada masa remaja, manusia mengalami kematangan dari segi fisik, psikologis, maupun sosialnya, perubahan yang mencolok adalah fisik, penyesuaian dan adaptasi dibutuhkan untuk menghadapi perubahan ini agar memperoleh identitas diri.

Pada masa remaja seseorang banyak mengalami perubahan, baik secara fisik maupun psikis. Perubahan yang pesat ini menimbulkan respon tersendiri bagi remaja berupa tingkah laku yang sangat memperhatikan perubahan bentuk tubuhnya. Para remaja melakukan berbagai usaha agar mendapatkan gambaran tubuh yang ideal sehingga terlihat menarik.

Penelitian ini sejalan dengan penelitian sebeelumnya yang dilkaukan oleh Sarafino (2010) yang mengatakan bahwa pada masa remaja, para remaja biasanya mulai bersibuk diri dengan penampilan fisik mereka dan ingin mengubah penampilan mereka. Keinginan ini disebabkan karea remaja sering merasa tidak puas terhadap penampilan dirinya.

\subsubsection{Perilaku Diet}

Hasil penelitian ini menunjukkan bahwa yang terbanyak yaitu remaja yang melakukan perilaku diet sebanyak 71 siswi (83,5\%). Tingginya angka kejadia ini disebabkan karena gadis remaja sering terjebak dengan perilaku makan yang tidak sehat, remaja menginginkan penurunan berat badan secara drastis dengan melakukan diet ketat bahkan sampai gangguan pola makan. Diet diyakini oleh remaja dapat memperbaiki penampilanya yaitu dengan membatasi konsumsi makanan. Pembatasan dalam jangka waktu tertentu terhadap konsumsi makanan dianggap dapat mengurangi lemak tubuh yang 
diikuti dengan menurunnya berat badan. Penurunan berat badan diharapkan dapat mengubah tubuh remaja menjadi semakin mendekati bentuk tubuh yang ideal.

Menurut Elga (2011). Diet merupakan kegiatan membatasi dan mengontrol makanan yang akan dimakan dengan tujuan untuk mengurangi dan mempertahankan berat badan. Diet merupakan salah satu cara yang paling popular untuk menurunkan berat badan karena diet dapat dilakukan oleh hampir semua orang.

Banyak dari kalangan remaja yang melakukan diet, berolahraga, melakukan perawatan tubuh, mengkonsumsi obat pelangsing dan lain-lain untuk mendapatkan berat badan yang ideal. Konsep tubuh yang ideal pada perempuan adalah tubuh langsing. Hal tersebut dikarenakan pada saat mulai memasuki masa remaja, seorang perempuan akan mengalami peningkatan lemak tubuh yang membuat tubuhnya semakin jauh dari bentuk tubuh yang ideal.

Penelitian ini sejalan dengan penelitian sebelumnya yang dilakukan oleh Hawks (2010) adalah usaha sadar seseorang dalam membatasi dan mengontrol makanan yang akan dimakan dengan tujuan untuk mengurangi dan mempertahankan berat badan. Hal ini mengakibatkan banyak dari remaja yang mengontrol berat badan dengan melakukan olahraga, mengkonsumsi obatobatan dan mencoba untuk membatasi makanannya.

\subsubsection{Hubungan Antara Masa Pubertas Dengan Perilaku Diet Pada Remaja Putri Di SMAN 2 WOHA Tahun 2017}

Hasil penelitian tentang hubungan masa pubertas dengan perilaku diet pada remaja putri di SMAN 2 WOHA ini menunjukan bahwa sebagian besar siswi pada masa pubertas yang mengkonsumsi dengan melakukan perilaku diet yaitu sebanyak 64 siswi $(92,8 \%)$, sedangkan siswi pada masa pubertas yang tidak mengkonsumsi dengan tidak melakukan perilaku diet yaitu sebanyak 9 siswi $(56,2 \%)$. Hasil uji statistik uji chi-Square P_value $(0,000) \leq \mathrm{a}(0,05)$ yang berarti bahwa secara statistik ada hubungan yang bermakna antara gangguan siklus menstruasi dengan tingkat stress di SMAN 2 WOHA Tahun 2017. 
Valencia (2010) mengemukakan bahwa gambaran tubuh bagi remaja merupakan suatu hal yang penting, karena pada masa remaja seseorang banyak mengalami perubahan, baik secara fisik maupun psikis. Perubahan yang pesat ini menimbulkan respon tersendiri bagi remaja berupa tingkah laku yang sangat memperhatikan perubahan bentuk tubuhnya.

Masa pubertas adalah masa yang relatitf singkat (yaitu, dua sampai empat tahun) dimana pemuda mengalami perkembangan fisik, termasuk mencapai kematangan rangka (yaitu, percepatan pertumbuhan) perkembangan karakteristik primer dan sekunder seksual (misalnya, payudara dan pertumbuhan penis). Para remaja biasanya mulai bersibuk diri dengan penampilan fisik mereka dan ingin mengubah penampilan mereka. Keinginan ini disebabkan karena remaja sering merasa tidak puas terhadap penampilan dirinya.

Penelitian ini sejalan dengan penelitian sebelumnya yang dilakukan oleh Papalia (2009) yang mengatakan bahwa memiliki gambaran tubuh yang ideal merupakan keinginan setiap remaja. Pada usia remaja banyak dari mereka yang berusaha mengubah penampilanya sehingga terlihat menarik. Begitu sadar berat badannya bertambah, biasanya orang akan mencoba membatasi makananya. Hal ini mengakibatkan banyak dari remaja yang mengontrol berat badan dengan melakukan diet dan berolahraga.

\section{Kesimpulan}

Dari hasil Penelitian dan Pembahasan yang dilakukan di SMAN 2 WOHA Tahun 2017 dapat disimpulkan bahwa: 1. Hubungan antara masa pubertas dengan perilaku diet pada remaja putri di SMAN 2 WOHA Tahun2017 yang terbanyak yang didapatkan adalah 64 siswi (92,8\%) pada masa pubertas yang mengkonsumsi, dan terdapat 9 siswi $(56,2 \%)$ pada masa pubertas yang tidak melakukan perilaku diet. 2. Ada hubungan yang bermakna antara Masa Pubertas Dengan Perilaku Diet Pada Remaja Putri Di SMAN 2 WOHA Tahun 2017 dengan Uji statistik Q_value $=(0,000)$. 


\section{DAFTAR PUSTAKA}

Attie, I. \& Brooks-Gunn, J. (2007). Development of Eating Problems in Adolescent

Girls: A Longitudinal Study. Developmental Psychology, 25(1), 70-79.

Cercq, dkk, (2010). Perilaku Kesehatan Pada Remaja, Study Pendahuluan di Semarang Indonesia Jurnal of Epidemiology, Vol 2 Edisi 1.

Dacey, J. \& Kenny, M. (2011). Adolescent development (2th ed). USA: Brown \& Benchmark Publishers.

Farida, Ida. (2010). Faktor-Faktor Yang Berbubungan Dengan Perilaku Konsumsi Buah Dan Sayur Pada Remaja Di Indonesia Tabun 2007, [Skripsi. Program Study Kesehatan Masyarakat Fakultas Kedokteran Dan Ilmu Kesehatan Universitas Islam Negeri Syarif Hidayatullah, Jakarta

Hawks, Stevan R. (2007). Classroom approach for managing dietary restraint, negative eating styles, and body image concerns among college women. Journal of American college health, Vol.56, No.4.

Hurlock. B. E. (2001). Psikologi Perkembangan: Suatu pendekatan sepanjang rentang kehidupan (Edisi Kelima). Jakarta: Penerbit Erlangga.

Kartono, K (2006) Psikologi Wanita. Bandung: Bandar Maju

Khomsan, Ali. (2004). Pangan Dan Gizi Untuk Kesehatan, PT. Raja Grafiindo Persada, Jakarta.

Notoadmojo, Soekidjo. (2003). Pengantar Pendidikan dan Perilaku Kesehatan, Rineka Cipta, Jakarta.

Ogden, J. (2007). Psichology of eating: From healthy to disordered behavior. USA: The Blackwell Publishing.

Papalia, D. E., Oldes, S. W., \& Feldman, R. D. (2008). Human development (Psikologi Perkembangan edisi Kesembilan). Jakarta: Kencana.

Santrock, J. W. (2003). Adolescence: Perkembangan remaja (edisi keenam). Jakarta: Penerbit Erlangga.

Sulistyoningsih. (2012), Perilaku Remaja. Bulletin Penelitian Kesehatan, Vil.30, No.1

Soetjiningsih, (2007). Tumbub Kembang Remaja dan Permasalahannya. Jakarta: Sagung Seto. 
Setiawan, A \& Saryono. (2011), Metodelogi Penelitian Kesehatan. Yogyakarta: Nuha Medika.

Verawati, S \& Rahayu, L. (2011). Merawat dan Menjaga Kesehatan Seksual Wanita. Bandung: Grafondo.

Wawan, A \& M, Dewi. (2011). Teori dan Pengukuran Sikap, dan Perilaku Manusia. Yogyakarta: Nuha Medika.

Sunaryo. (2004) Psikologi Untuk Keperawatan. Jakarta : EGC. 